\title{
Supporting change in VET: teachers' professional development and ECVET learner mobility
}

\author{
Cathal de Paor ${ }^{*}$ (1)
}

*Correspondence:

cathal.depaor@mic.ul.ie

Faculty of Education,

Mary Immaculate College,

University of Limerick,

Limerick, Ireland

\begin{abstract}
Background: While mobility to other countries has become very much a part of higher education programmes, VET learners have not participated to the same extent. The possibility which European Credit System for Vocational Education and Training (ECVET) offers in terms of the transfer, recognition and, accumulation of learning outcomes may help to change this. However, this requires a considerable involvement from teachers, given the role they need to play in preparing for such mobility in terms of learning outcomes, learning activities and assessment.
\end{abstract}

Methods: This paper considers the professional development needs of teachers with regard to this, drawing on the results of an Erasmus + Strategic Partnership, QUAKE, geared towards teacher professional development and learner ECVET mobility in a number of European countries. The project provides the basis for an explanatory case study (Yin 1994), and the case results being considered here are drawn from the views expressed by Irish VET teachers.

Results: The results highlight the need for a greater connection between VET teachers' professional development and their routine work with learners.

Conclusions: ECVET mobility can contribute to this connection, providing the context where the professional development becomes an integral part of the teaching and learning process, thereby ensuring a more successful adoption of educational change.

Keywords: ECVET, Mobility, CPD, Teacher learning, Learning outcomes

\section{Background}

Mobility is a key aim in European education and training policy, currently supported by programmes such as Erasmus+, the EU Programme in the fields of education, training, youth and sport for the period 2014-2020 (European Commission 2013). In research terms, one concrete example of the increasing importance of mobility is the existence of an academic journal dedicated solely to the issue, Journal of International Mobility, published in France. However, while much progress has been achieved in promoting mobility in higher education, there is some way to go before learner mobility in VET can reach the same level. Yet, learner mobility has become a greater priority in VET, in the last 15 years, due in part to labour market needs and increasing European cooperation in VET. This is particularly so since the adoption of the Copenhagen declaration signed by

(c) The Author(s) 2018. This article is distributed under the terms of the Creative Commons Attribution 4.0 International License (http://creativecommons.org/licenses/by/4.0/), which permits unrestricted use, distribution, and reproduction in any medium, provided you give appropriate credit to the original author(s) and the source, provide a link to the Creative Commons license, and indicate if changes were made. 
EU ministers responsible for VET, which has now become part of Education and training 2020 (European Union 2009).

Thus, for example, following a recommendation from the Commission (European Union 2010), CEDEFOP set up the Mobility Scoreboard, helping policy-makers develop mobility in Initial education and training (IVET) across Europe, and identifying good practice in supporting the mobility of learners. Currently, 27 countries fund VET learners to stay abroad, while 24 countries support cross-European partnerships between IVET institutions and companies (CEDEFOP 2016a). In 2015, Eurostat calculated (based on 2014 data from 16 Member States) that, on average, 3.1\% of IVET learners at International Standard Classification of Education (ISCED) level 3 (upper secondary education) travel for learning. By 2020, the goal of the European Council is that at least $6 \%$ of all 18-34 year-olds with a VET background be granted a learning experience abroad.

However, less progress is being made with regard to the recognition of skills and knowledge acquired during such mobilities as reported (CEDEFOP 2016a). The mobilities undertaken within the new European Credit System for Vocational Education and Training (ECVET) are designed to address this, as we shall see.

Mobility in higher education gives students the opportunity to study modules that are relevant for their programme of studies, and to develop other knowledge and skills in the process, for example, foreign language skills. But there is also something even more ambitious happening in vocational education and training. This is because, an ECVET mobility requires both institutions, together with the learner to devise a customised programme (rather than a module that is already being offered), with the agreed learning outcomes being assessed during the placement. These assessed learning outcomes are then transferred home, and are validated by the students' home institution.

The adoption of ECVET draws attention to the capacity of individual countries to facilitate such a system and monitoring reports show that progress in ECVET implementation has been slow (CEDEFOP 2016d). It is now being increasingly recognised, that apart from system capacity, it is crucial that teachers have the knowledge and skills to promote and enable such learner mobility. This raises the issue of continuing professional development (CPD) for teachers. The paper considers what the focus of such CPD should be and how its design might reflect what we know already about the features of effective CPD from the literature as a means of supporting educational change. It draws on the results of an Erasmus+ Strategic Partnership, QUAKE, which worked with VET teachers on a range of professional development activities, geared towards their greater use of learner mobility within the context of ECVET. The paper argues that addressing teacher professional development needs is crucial for promoting successful learner mobility, and for greater progress in the adoption of ECVET across Europe.

\section{Literature review}

This literature review begins with some further detail on ECVET, before considering relevant insights from the literature on VET teachers' CPD and educational change.

European Credit System for Vocational Education and Training is an initiative promoted at European level, designed as a technical framework for the transfer, recognition and, where appropriate, accumulation of learning outcomes by learners in VET, thereby promoting transnational mobility and access to lifelong learning. This facilitates the 
recognition of achievements in VET, in formal, informal and non-formal learning. It has been tested in pilot projects across the European Union with the intention of extending its application gradually to a wider range of VET qualifications, either existing or new - as part of the Education and Training 2020 initiative. However, there remains a certain levels of opposition to the full scale adoption of ECVET. Much of this relates to the use of learning outcomes, and the proposition within ECVET to assess them independently of learning context and duration, as shown by Krichewsky in the case of Germany (2016).

At the same time, it is not always possible to identify exactly what has been achieved as a result of ECVET. As stated in the Director's foreword in the latest CEDEFOP monitoring report, it is 'difficult to separate the development and implementation of ECVET principles from the developments of national qualification frameworks'. The Director concludes that, 'progress has been achieved (as can be evidenced from this fifth report) but more commitment towards establishing a credit system for VET that is transparent across all Member States is increasingly becoming the next step in a quality VET system. More Member States need to link credits in VET to the common platform of ECVET' (CEDEFOP 2016d, p. 2). Elsewhere, Pilz et al. (2017) report that tools such as ECVET have helped in promoting modularisation in VET, this being a necessary component in the drive towards modernisation. In this way, therefore, ECVET has acted as a catalyst in adding to the momentum for other necessary reforms. This can be seen in the case of Hungary and Poland (Kurek and Rachwal 2012; CEDEFOP 2016c). Its adoption corresponds more generally to the increasing internationalisation in VET (Tran and Dempsey 2017).

Ongoing support for ECVET has also ensured that it continues to provide the basis for small-scale projects, as reported routinely in the magazine published by the ECVET Secretariat, the latest of which also reports on the most recent ECVET Forum (ECVET Secretariat 2017). Such projects also prove the basis for research articles published in the research literature. For example, research conducted within the MASECVET project in the automotive industry, concludes that the application and implementation of the EQF and ECVET in combination with operational approaches can provide, 'greater transparency and comparability of qualifications across borders, but also as a catalyst for quality, labor market responsiveness and innovation within VET in general and in the automotive sector in particular' (Ozcan et al. 2017, p. 91).

There are of course many factors which determine the extent of ECVET adoption, including the availability of national credit systems that are compatible with the credit point system proposed in ECVET and the use of learning outcomes (CEDEFOP 2016d). However, it is also being increasingly recognised from monitoring that teachers and trainers are an important key to unlocking the potential of ECVET, and that these, 'teachers and trainers need additional/special competences to use learning outcomes for teaching and assessing' (CEDEFOP 2014, p. 90). This aspect of ECVET implementation has received little attention, i.e., the professional development needs of those who play a key role in promoting it and ensuring its greater implementation-the teachers.

It is for this reason that QUAKE has focused its activity on the professional development of teachers, mobilising teachers, as it were, so that they in turn can mobilise their learners. Such a focus on the professional development of teachers reflects the 
realisation that, apart from the need for the necessary policies at a system level, the use of ECVET depends on the knowledge, skill and attitudes of teachers who will ultimately be the people who drive it and make it happen.

\section{VET teachers' professional development and educational change}

This paper therefore addresses ECVET adoption as an example of education change that requires teacher professional engagement and agency. This focus provides the basis for the use of Guskey's model of education change as a theoretical framework. The model proposes that significant changes in the beliefs of teachers are likely to take place only after teachers have 'field-tested' change proposals themselves and experienced firsthand change in student learning outcomes (2002, p. 382). The key element in Guskey's model is the evidence of improvement in learning. In other words, the extent to which the change is perceived by teachers as benefiting teaching and learning becomes key in how successful the implementation is. This therefore highlights the need for professional development that involves teachers in undertaking the kinds of activities associated with the educational change that is being sought.

This connection between teacher professional development and their adoption of educational change is also supported in the broader CPD literature. Research has shown for quite some time that CPD provision should be experiential, grounded in enquiry, collaborative, sustained and derived from teachers' work with their students (DarlingHammond and McLaughlin 1996). As more recently discussed by Darling Hammond, the job-embedded forms of professional learning which reflect this, 'are taking greater root, often organised around teachers' work with curriculum development through collaborative planning, lesson study and action research of various kinds' (2017, p. 303).

Elsewhere, the OECD notes that the most effective forms of professional development are those that, 'focus on clearly articulated priorities, provide ongoing school-based support to classroom teachers, deal with subject matter content... and create opportunities for teachers to observe, experience and try new teaching methods' (OECD 2005, p. 129). This is also borne out by studies focused specifically on the professional development of VET teachers. For example, in a study on effective CPD for VET teachers, the teachers believed that professional development was not just about going on courses, but rather 'about learning from each other, discussing different ideas, experimenting with new approaches to teaching and reflecting on their own practice' (Lloyd and Payne 2012, p. 11).

European Credit System for Vocational Education and Training provides a context therefore where the views of teachers on what CPD is needed to support educational change can be further explored. This provides the basis for the research being reported here, and indeed also provides the basis for the focus of the project itself, as outlined below.

Such a focus on VET teachers' CPD is all the more necessary given, as demonstrated previously in this journal that 'research concerning vocational teachers' CPD is not extensive' (Andersson and Köpsén 2015, p. 3). And yet, such research is all the more necessary given the particular needs with regard to 'dual professionalism, i.e., the need to be knowledgeable about the vocational area (often having experience from industry), as well as the pedagogical expertise. In other words, unlike teachers in other sectors, VET 
teachers have a 'vocational identity and a teacher identity', and yet little is known about how these interact and how they can be best supported. The situation is also rendered complex given that these teachers may work in various VET systems and programmes (e.g. Billett 2011). Consequently, it is not a clearly defined profession (Misra 2011; Parsons et al. 2009).

A further complication relates to the need for integration between the learning that happens in the workplace (while learners are on placement for example) and in the VET setting (school, college, centre, etc.). This has led to some attempts to approach the professional development of teachers and work-place trainers or mentors in a unified way where possible, for example in the CEDEFOP policy learning forum on the 'professional development of vocational education and training (VET) teachers and trainers' (CEDEFOP 2016b).

This provides the context for the focus on the CPD needs of VET teachers as illustrated in the QUAKE project. Although the extent of the results are limited, they do nonetheless give an insight into the kinds of needs which arise when teachers are asked about their view on implementing learner mobility, in line with ECVET, in their work.

\section{QUAKE}

QUAKE was an Erasmus+ Strategic Partnership (KA2) involving seven partners from five European countries (Belgium, Bulgaria, France, Ireland, and Spain), bringing together government ministries, higher education institutions, and a provider of VET. ${ }^{1}$ The project sought to promote the use of ECVET in the horticultural sector by supporting VET teachers in this sector with a range of professional development activities.

Opting to confine the project activities to one domain only-horticulture-and one level (EQF 4), ensured that the participating teachers were all working in similar contexts, thereby increasing the possibility that suitable mobilities could be arranged for their learners between the settings represented. The focus on a land-based vocational area was due to the composition of the project group, which included partners from ministries of agriculture, ministries of education, higher education institutions (HEI) involved in the preparation of agricultural professionals, as well as a VET provider with access to schools/colleges and enterprises involved in horticulture. The countries involved were at varying stages of ECVET implementation more generally in their VET sector.

The project included a range of activities over 3 years as briefly presented in Table 1, beginning in September 2014 and continuing up until the end of August 2017. The first of these was an état des lieux of ECVET adoption and VET teacher education within each country. This informed the design of the first programme of CPD delivered in Year 2 (November 2015) to 25 VET teachers gathered in Orléans, France i.e., five teachers from each of the participating countries. This gathering also enabled teachers to begin identifying possible partners for the mobility of their learners later on in the project. The online training programme which followed built on the initial training, enabling teachers to continue exploring possibilities and developing relationships. While some learner mobilities began to happen in Year 2, most took place in Spring 2017 (Year 3), with the

\footnotetext{
${ }^{1}$ For more on QUAKE, see http://www.projetquake.eu.
} 
Table 1 Key activities from project commencement (Sept. 2014) to project end (Aug. 2017)

\begin{tabular}{|c|c|c|}
\hline Timeline & Key activity & Description \\
\hline Sept. 2014-Jan. 2015 & CPD needs analysis and état des lieux & $\begin{array}{l}\text { CPD needs analysis based on various data col- } \\
\text { lection activities in each of the five countries, } \\
\text { including the focus group interview of six Irish } \\
\text { VET teachers, which provides the data for this } \\
\text { paper; also an 'état des lieux'of ECVET imple- } \\
\text { mentation in Europe }\end{array}$ \\
\hline Nov. 2015 & CPD event \#1 & $\begin{array}{l}\text { Week-long CPD event for } 25 \text { teachers; } 5 \text { teachers } \\
\text { from each of the five QUAKE countries, held in } \\
\text { Orléans }\end{array}$ \\
\hline Jan. 2016-end & CPD online & $\begin{array}{l}\text { Online CPD programme for teachers to advance } \\
\text { preparation for learner mobility, share } \\
\text { resources, etc. }\end{array}$ \\
\hline May 2016-July 2017 & Learner mobility & $\begin{array}{l}\text { VET teachers prepare and implement learner } \\
\text { mobilities between five countries }\end{array}$ \\
\hline March 2017 & CPD event \#2 & $\begin{array}{l}\text { Further professional development; review of the } \\
\text { mobilities; planning for future collaborations; } \\
\text { attended by } 25 \text { teachers; held in Bruxelles }\end{array}$ \\
\hline
\end{tabular}

return of the growing season offering more scope for teachers to use practical activities to match the learning outcomes being targeted. The participating teachers reconvened for a second face-to-face week of CPD in March 2017 in Brussels.

\section{Methodology}

The QUAKE project is therefore being used as the basis for a case study, and more particularly as an explanatory case study (Yin 1994). Such a case study is the preferred option where (a) the project to be studied is not easily distinguished from the broader context and (b) there are many variables of interest. Within the case study, the results being considered here are drawn from a focus group of six Irish VET teachers conducted in January 2015.

This focus group was brought together using a convenience sample, with all of the teachers working for Limerick and Clare Education and Training Board teaching VET programmes in a number of different settings. These included the Post-Leaving Certificate (PLC) sector (corresponding to the post-secondary non-higher education and training sector), as well as teachers working on the Vocational Education and Training Scheme (VTOS) aimed at unemployed learned aged at least 21 years in centres of education and training. The interview lasted $40 \mathrm{~min}$ and was recorded and transcribed. The usual assurances relating to confidentiality and anonymity were given to the participating teachers.

The discussion during the focus group was initiated by asking teachers to have read in advance a case study of a Finnish learner, Rosa, who had already undertaken an ECVET mobility in Iceland as part of her programme of tourism studies in Finland (Finnish Board of Education 2012). The discussion focused in particular on what was needed to be done before, during and after the mobility, and what implications it raised for the professional knowledge of teachers. Guiding customers from different countries while using a foreign language herself were some of the reasons used to determine the learning outcomes chosen, as well as developing competence in organising various horse-riding events in Iceland. In accordance with ECVET principles and procedures, a 
Memorandum of understanding was concluded with an Icelandic educational institution in the tourism industry. A Learning Agreement was signed by Rosa, the Icelandic institution and the horse-riding event organiser.

This scenario served as a way of raising initial awareness of ECVET among the Irish teachers, focusing their attention on what they might need to undertake a similar mobility with their own learners, or to host an ECVET mobility themselves. All of the teachers had experience in teaching VET programmes at level 4 on the EQF, (the equivalent of level 5 in the Irish NFQ).

These results of the focus group were then used, along with results from the other countries, in the design of the first professional development event held in Orléans in November 2015. For example, prior to that event, teachers were asked to prepare a profile of their VET setting and targeted programme, and to share these with the teachers due to attend from other countries. This enabled the teachers to begin identifying possible receiving institutions with which they might partner, as well as possible modules, learning outcomes and assessment approaches. The event itself provided ample time for teachers to explore mobility possibilities and to discuss the more technical aspects relating to assessment of learning outcomes.

The focus group results were analysed using thematic analysis, involving a number of stages as advocated by Yin (1994), i.e., examining, categorising and tabulating or otherwise recombining the evidence, in order to address the initial goal.

These results are interpreted in the discussion below in light of the overall achievements of the project as published on the project website.

\section{Results}

The results illustrate the immediate needs of the VET teachers, as perceived by them, were they to embark upon the use of ECVET mobilities with their own learners.

\section{Technical aspects of ECVET}

The first need identified related to the technical aspects of ECVET, so that teachers could go on to discuss, plan and agree ECVET mobilities with colleagues abroad: 'a common glossary of the host, teacher, the learning agreement, the assessment grade, very useful tools for a student to move forward if they are using the one language; to get your head around the terminology that would be common for everyone to agree on'.

\section{Assessment of learning outcomes}

A second key issue related to the assessment of learning outcomes as part of the mobility, and accepting or validating that assessment when the learner returned. This raised the question of competence and trust. Teachers needed the competence to create suitable assessment tasks and to carry out the assessment in a valid and agreed way. In the case of a learner being placed in an enterprise, they needed to make sure that the workplace mentor or supervisor also had the competence to carry out the assessment.

Entrusting the assessment of the learning to a teacher in another country was a new prospect for teachers. They had arranged mobilities abroad previously, but the assessment tended to be on a pass/fail basis, rather than involving a more gradated judgement on the learning. This would require greater clarity regarding the interpretation of the 
planned learning outcomes, and agreement on a suitable work programme to support their achievement: 'You're talking about learning outcomes. It's quite broad but I think you actually need to break that down'. It would require agreement on the levels of mastery for each target skill, involving the creation of rubrics, with 'standards for the assessment of any work produced.... Depending on the scope of the placement, it would also be more appropriate to target learning outcomes from two or even more $=$ modules. This would pose a certain challenge for teachers, requiring them to collaborate with colleagues in their own institutions (being a little more complicated than if the learning outcomes all came from the same module). In fact, in line with recommendations from the Irish competent authority for the VET award (QQI 2013) teachers were already being encouraged to consider combining assessments, across modules, and where necessary, working with other teachers within the setting in doing so. This meant that a learner might submit one piece of course work that could meet the requirements for learning outcomes taken from more than one module.

Teachers also mentioned the need to learn new approaches for their own teaching practices, including ICT skills with regard to assessment, e.g. teaching learners to gather evidence illustrating task completion, and assembling portfolios. Where they were receiving learners themselves, they would need to supervise the learner in this kind of ongoing assessment: 'embedding a video, like we don't have all the skills, if they were uploading a video of themselves during the task... the students could film themselves carrying out a particular task... moving to an eportfolio then'. The increased use of technology would also be necessary even from an organisational and administrative point of view, allowing them to engage in the collaborative planning for the mobility, and where necessary, keeping in regular contact and sharing resources with other teachers.

Teachers also recognised that learners on placement would develop other knowledge and skills outside of the learning outcomes, through non-formal and informal learning. Being able to encourage this learning, and to valorise it was also necessary so that the mobility could be successful.

\section{Deciding on a suitable placement}

Another point of discussion concerned the identification of a partner. Given the focus on horticulture, teachers were of the view that the receiving institution would also need to have ready access to a garden where learners could practice skills, rather than relying on a classroom only. Alternatively, the educational institution would need to have access to placement settings in an enterprise. Teachers were of the view that a focus on skills development during the mobility was more feasible, thereby necessitating practical experience, rather than a classroom experience: 'I will say that it's going to be more skills-based and it would be either going more to employers or even let's say in our college we'd have a lot of practical [activities] [...] but I would say that it would be more skills and practical-based rather than going into class.' Such an environment would provide a more suitable context for learning, and enable a more appropriate assessment of the targeted learning outcomes: 'It would cover your assessment for workplace and it probably also will cover some skills from food crops and maybe in plant identification and so on'. 
There was also some discussion on teachers' capacity to advise learners on choosing a placement. Teachers believed that the learners should have a major role in any decisions about the choice of host institution, for reasons relating to motivation and personal investment, but as teachers, they needed to be able to provide advice. In the Finnish case study, Rosa had been able to combine her programme learning needs with her passion for horses by choosing an equestrian centre. She planned the skills in an area already familiar to her, and directly related to her programme of study in her home institution. This also raised administrative issues with regard to selection and approval, especially, where the number of places might be limited.

Overall, teachers were of the view that a significant amount of preparation was required. The use of ECVET would also depend a lot on the level and autonomy of teachers in the other countries. In order to plan collaboratively with teachers in these other countries, and as illustrated in their comments above, they needed certain skills in technology, and access to a range of resources, such as guidelines and reference material, with practical examples of successful mobilities such as the Finnish case study. Professional development which targeted these needs would benefit not just the implementation of the ECVET scheme, but also develop their own teaching practice more generally.

\section{Discussion}

The results show the initial response of teachers to the prospect of participating as a sending or receiving teacher in an ECVET mobility, i.e., supporting the mobility of their own learners abroad, or hosting a mobility from learners from other countries to their own institution. Clearly, teachers need support, if the potential of ECVET for their learners can be realised.

The results illustrate the validity of the model of teacher change proposed by Guskey, as their responses point to the need for opportunities to engage in real collaborations with their counterparts in other countries. The results show the need for professional development to link directly with student learning, given the centrality of the learning outcomes. There was also a need for teachers to deepen their knowledge about teaching, learning and assessment, more generally, particularly with regard to the alignment between what is taught or practised, what is learned and what is assessed.

These results can be interpreted in light of what was achieved afterwards over the duration of the project. It later became clear as the mobilities were completed, that there were some differences in how the assessment of learning outcomes was carried out. Some of the mobilities involved a graded assessment of the learners' achievements against particular learning outcomes, while for others, the learning was assessed in a less gradated way, i.e., successful/unsuccessful. Some mobilities were also based on units of learning outcomes that corresponded to a placement or practice module from the learner's home programme, while other mobilities attempted to also target LOs taken from taught modules. There is scope therefore in future work to design learner agreements that target outcomes from more than one unit or module. The way in which assessment results are incorporated with the learners' other results in their home institution also emerged as an important issue.

What is significant from the results is the confirmation it provides for the merit of requiring teachers to carry out learner mobilities as part of the $\mathrm{CPD}$, ensuring that 
engagement was more meaningful and therefore more productive. This provided a context for the professional development, and meant that the professional development was experienced as, 'an ongoing activity woven into the fabric of every educator's professional life' (Guskey 2000, p. 38).

There were of course various challenges in integrating the CPD with the actual task of planning and undertaking ECVET mobilities. For example, in accordance with Erasmus+ rules at the time, a week was the minimum duration for both face-to-face CPD events that were organised. While this provided the necessary time and space for the teachers to engage fully in the professional dialogue, it also posed a challenge for many in securing release from their VET settings. On the other hand, the online component for the CPD supported ongoing collaboration.

Addressing the professional development needs of VET teachers is not so straightforward. Various reasons were advanced for this in the discussion earlier, including in the argument that the 'Vocational teacher' is not a clearly defined profession (Misra 2011). In Ireland, SOLAS has adopted the term VET 'practitioner', as a unified way of understanding the sector workforce. The FET practitioner can be defined as anyone working in the sector who is involved in working directly with learners or in supporting or influencing the learner experience in FET (SOLAS 2016, p. 16). In Europe, CEFEFOP refers to teachers and trainers, with the latter referring to professionals based in enterprise who have a role in supporting learning, for example, mentors and supervisors (CEDEFOP 2016b). In any case, the important point is that CPD provision for VET teachers is now a major priority, and designing effective CPD in a VET context raises particular issues. This is also the case within the specific situation of ECVET as an example of education change that depends so much on the agency and investment of the VET teachers concerned.

Also of note is the fact that the teachers in this study referred to skills in liaising with industry, and securing their participation in a mobility that would involve additional competence, including the assessment of specific learning outcomes. This reflects the increasing importance of contact between the VET setting and enterprise. In fact, staying with the Irish context, employer engagement is one of the priorities identified in the SOLAS FET Strategy, involving, 'relationship building, partnership working and, ultimately, more systematic involvement of employers in the planning, design and delivery of relevant FET provision' (SOLAS 2016, p. 35). The strategy emphasises that, 'FET leaders increasingly identify the need for FET practitioners to play an effective role in employer engagement and therefore identify this area as a key skill requirement' (SOLAS 2016, p. 35).

The role of teachers is crucial therefore in moving ECVET to the next stage in its adoption and use. Progress on ECVET implementation has not been as uniform or as swift as intended, and has led to some a certain disillusionment in certain cases, as illustrated by the following statement from the Director of CEDEFOP:' It is disheartening to think that after almost twelve years... the VET community has not established a credit system for VET. One can easily determine that so far actions have transformed end-users into endlosers... It is time to adopt an ECTS version for ECVET which is clear and consistent enough to lodge all forms of learning in clusters of determined hours (more or less $25 \mathrm{~h}$ for each credit) (Calleja 2014). 
Apart from questions of credit systems, however, there is so much about ECVET that is congruent with other trends in education in the 21st century, for example, greater integration between learning across multiple sites, and greater scope for teachers to create engaging learning pathways that take account of the individual learning needs of learners. There is also the added benefit for teachers that learning about practice in other countries has provided them with the prompt to reflect more deeply on what they are already doing at home.

\section{Conclusion}

Given the scale of the case study, the results are only suggestive and cannot be generalized. However, they do suggest a need for a greater connection between VET teachers' professional development and their work with learners. ECVET mobility can contribute to the connection, providing the context where the professional development becomes an integral part of the teaching and learning process.

In drawing on Guskey's model of teacher change, and reflecting on the kinds of needs identified by teachers, the analysis shows the merit in building the professional development around the actual engagement in the education change being proposed, i.e., involving them in the ECVET mobility of their own learners. As discussed earlier, teachers are more inclined to adopt new practices, where they have had a chance to experience the benefits for themselves. It is therefore imperative that teachers are supported and motivated to 'try out' the use of ECVET collaborations with counterparts in other countries. Following Guskey's model, a change in practice, even in an experimental context such as the one use here, should be more effective in leading ultimately to a change in attitude.

Overall, the project results show that the implementation of ECVET depends on teachers having the knowledge, inclination and support to embark upon partnerships with colleagues in other countries. As in the world of horticulture itself, future growth depends on action from the ground up, as well as from the top down. Support for relatively small-scale projects such as QUAKE is therefore crucial-helping to break new ground for those involved, and to cultivate it for greater returns in the future.

While the acronym for this Erasmus+ Strategic Partnership was chosen as an attempt to 'shake things up a bit' in the world of qualifications, the official project title-de la conception pour les apprenants a la professionnalisation des enseignants-conveys more fully what the project has been trying to do and with whom. It refers to both learners and teachers, the starting point of ECVET being the learners' learning, but with the professional practice of teachers being crucial in realising its potential. In fact, while QUAKE has involved the mobility of both learners and teachers, it can be said that it has had a particular emphasis on the 'mobilisation' (not just the mobility) of teachers.

The paper shows the importance of professional development for teachers in the use of European tools such as ECVET. The needs analysis provides some insight into the initial views of teachers with regard to their needs. Given the nature of these needs, and the very diverse contexts in which VET teachers are working across Europe, it is readily obvious why addressing these needs is crucial in ensuring the kind of educational change necessary for ECVET adoption. Similar to the learning outcomes paradigm upon which it is based, ECVET may strive to place the learner at the centre, but here is a need to reflect the fact that teachers are also central. 
While professional development for VET practitioners has been on the EU education policy for some time, the Riga conclusions (2015) have put renewed emphasis on the issue, calling for systematic approaches to and opportunities for initial teacher education and continuing professional development (CPD) of VET teachers, trainers and mentors. In Ireland, in line with its statutory responsibilities, SOLAS, the new authority for further education and training in Ireland, along with ETBI (Education and Training Boards Ireland) has recently published its professional development strategy for VET practitioner, recognising that, 'The complex and changing nature of the FET practitioner role means that professional development is vital to a workforce that has to anticipate, respond to and meet the needs of a constantly evolving economy and society' (SOLAS 2016, p. 17).

And in the case of VET teachers, the Irish Teaching Council is also currently developing a CPD framework (Teaching Council 2015). Projects such as the one reported here can play a useful role in providing such professional development. In fact, EU-funded projects have acted as, 'significant drivers of teacher and in-company trainer professional development' (CEDEFOP 2016b).

In a more general way, future research in VET will need to take account of the increasing mobility of learners and their learning, thereby contributing more effectively to working the spaces between policy and practice, the practice of teachers in curriculum and assessment, and the practice of learners in creating their own learning journeys across multiple sites. This is true not just in the case of ECVET, but in all areas of educational change and endeavour.

Acknowledgements

The data was collected as part of an Erasmus + European Strategic Partnership, QUAKE (Qualifications Knowledge ECVET), funded by the European Commission.

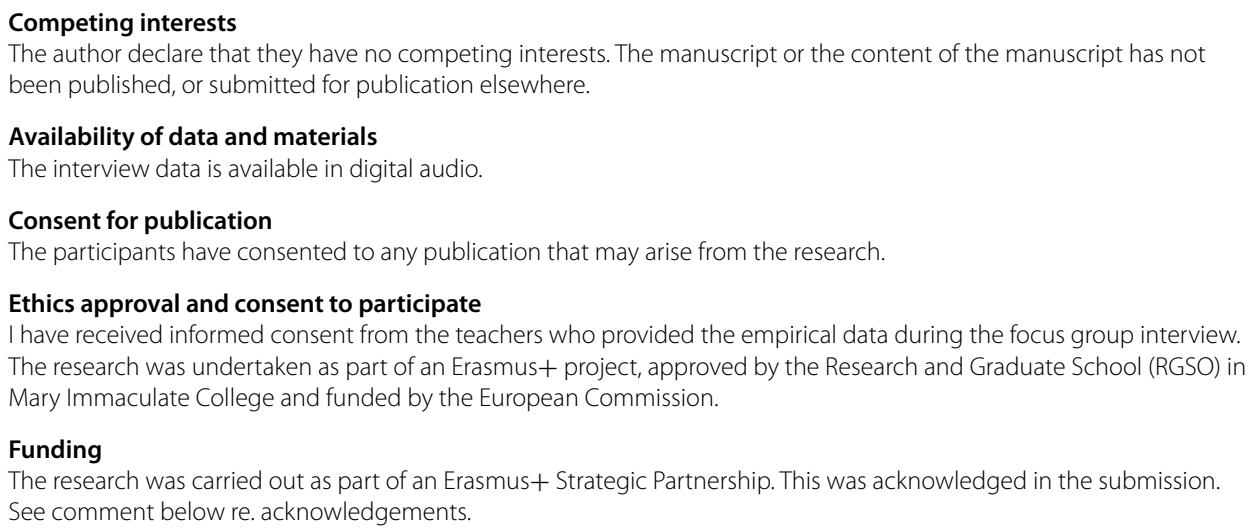

\section{Publisher's Note}

Springer Nature remains neutral with regard to jurisdictional claims in published maps and institutional affiliations.

Received: 18 August 2017 Accepted: 22 December 2017

Published online: 06 January 2018 
Billett S (2011) Vocational education: purposes, traditions and prospects. Springer, New York

Calleja J (2014) Editorial—-to be or not to be, that is the answer. ECVET Magazine, 21, pp 2-3. http://www.ecvet.nl/ uploads/ECVET/Magazinedec201421.pdf

CEDEFOP (2014) Monitoring ECVET implementation strategies in Europe in 2013. Thessaloniki, CEDEFOP_European Centre for the Development of Vocational Training. http://www.cedefop.europa.eu/en/publications-and-resources/ publications/6122. Accessed 20 Dec 2017

CEDEFOP (2016a) Supporting training and learning abroad: the EU mobility scoreboard for initial VET. Briefing Note. Thessaloniki, CEDEFOP. http://www.cedefop.europa.eu/fr/publications-and-resources/publications/9114. Accessed 20 Dec 2017

CEDEFOP (2016b) Professional development for VET teachers and trainers. Thessaloniki, CEDEFOP. http://www.cedefop. europa.eu/en/publications-and-resources/publications/9112. Accessed 20 Dec 2017

CEDEFOP (2016c) Application of learning outcomes approaches across Europe. Thessaloniki, CEDEFOP. http://www. cedefop.europa.eu/en/publications-and-resources/publications/3074. Accessed 20 Dec 2017

CEDEFOP (2016d) Monitoring ECVET implementation strategies in Europe in 2015. Thessaloniki, CEDEFOP_European Centre for the Development of Vocational Training. http://www.cedefop.europa.eu/en/publications-and-resources/ publications/5556. Accessed 20 Dec 2017

Darling-Hammond L (2017) Teacher education around the world: what can we learn from international practice? Eur J Teach Educ 40(3):291-309

Darling-Hammond L, McLaughlin MW (1996) Policies that support professional development in an era of reform. In: McLaughlin MW, Oberman I (eds) Teacher learning: new policies, new practices. Teachers College Press, New York

ECVET Secretariat (2017) ECVET Magazine 30. http://www.ecvet-secretariat.eu/en/system/files/magazines/en/ecvet_ mag_30.pdf

European Commission (2013) Regulation (EU) No 1288/2013 of the European Parliament and of the Council of 11 December 2013 establishing 'Erasmus+': the Union programme for education, training, youth and sport and repealing decisions No 1719/2006/EC, No 1720/2006/EC and No 1298/2008/EC text with EEA relevance. Office for Official Publications of the European Communities, Luxembourg. http://eurlex.europa.eu/eli/reg/2013/1288/oj. Accessed 20 Dec 2017

European Union (2009) EU cooperation in education and training (ET 2020). http://eur-lex.europa.eu/legal-content/EN/ TXT/?uri=uriserv:ef0016

European Union (2010) Youth on the move-promoting the learning mobility of young people. Luxembourg, Publications Office of the European Union. http://europa.eu/youthonthemove/docs/communication/ youth-on-the-move_EN.pdf

Finnish Board of Education (2012) FINECVET as a pioneer: from piloting to implementation. http://www.oph.fi/download/143718_Finecvet_as_a_pioneer.pdf

Guskey T (2000) Evaluating professional development. Corwin Press, Thousand Oaks

Guskey T (2002) Does it make a difference? Evaluating professional development. Educ Leadersh 59(6):9-27

Krichewsky L (2016) Les dispositifs de validation et de reconnaissance des compétences acquises dans le cadre d'une mobilité: un révélateur de l'internationalisation du système de formation professionnelle en Allemagne. J Int Mobil 4(1):75-90

Kurek S, Rachwał T (2012) Vocational education and training in Poland during economic transition. In: Pilz M (ed) The future of vocational education and training in a changing world. Springer, Wiesbaden, pp 321-340

Lloyd C, Payne J (2012) Raising the quality of vocational teachers: continuing professional development in England Wales and Norway. Res Pap Educ 27(1):1-18. https://doi.org/10.1080/02671522.2010.483524

Misra PK (2011) VET teachers in Europe: policies, practices and challenges. J Vocat Educ Train 63:27-45

OECD (2005) Teachers matter attracting, developing and retaining effective teachers. Organisation for Economic Cooperation and Development, Paris

Ozcan M, Vuranok T, Ball C (2017) Assessment of electromechanic technician qualifications in the context of European transparency tools. Eurasian J Educ Res 71:79-96. https://doi.org/10.14689/ejer.2017.71.5

Parsons D, Hughes J, Allison C, Walsh K (2009) The training and development of VET teachers and trainers in Europe. In: European centre for the development of vocational training (CEDEFOP) modernising vocational education and training (Fourth report on vocational training research in Europe: background report), vol 2. Office for Official Publications of the European Communities, Luxembourg. www.cedefop.europa.eu/files/3050_II_en.pdf. Accessed 20 Dec 2017

Pilz M, Li J, Canning R, Minty S (2017) Modularisation approaches in Initial Vocational Education: evidence for policy convergence in Europe? JVocat Educ Train. https://doi.org/10.1080/13636820.2017.1392994

QQI (2013) Quality assuring assessment guidelines for providers. Dublin, Quality and Qualifications Ireland. http:// www.qqi.ie/Downloads/Quality\%20Assuring\%20Assessment\%20-\%20Guidelines\%20for\%20Providers\%2C\%20 Revised\%202013.pdf

SOLAS (2016) FET strategy, 2017-2019. Dublin, SOLAS and ETBI. http://www.solas.ie/SolasPdfLibrary/SolasFETPDS.pdf

Teaching Council (2015) Cosán, the National framework for teachers'learning. Maynooth, The Teaching Council. http:// www.teachingcouncil.ie/en/Publications/Teacher-Education/Cosan-Framework-for-Teachers-Learning.pdf

Tran TL, Dempsey K (eds) (2017) Internationalization in vocational education and training: transnational perspectives. Springer, Dordrecht

Yin RK (1994) Case study research: design and methods. Sage, Thousand Oaks 